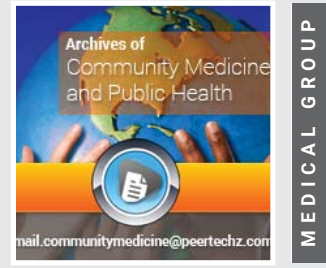

\title{
Possibility of Community
}

\section{Transmission of COVID 2019}

\section{Infection In India: A WTSO}

\section{Analysis Outcomes}

Received: 31 March, 2020
Accepted: 08 May, 2020

Published: 09 May, 2020

*Corresponding author: Dr. Sanjeev Davey, Professor Department of Community Medicine, Muzaffarnagar Medical College, Muzaffarnar, UP, India, E-mail: Sanjeevdavey333@gmail.com

Keywords: TOWS analysis; Community transmission; COVId 2019 infection; India; Case series

https://www.peertechz.com

\section{Check for updates}

\author{
Sanjeev Davey ${ }^{1 *}$, Anuradha Davey² and Rajesh Jain ${ }^{3}$ \\ ${ }^{1}$ Department of Community Medicine, Muzaffarnagar Medical College, Muzaffarnar, UP, India \\ ${ }^{2}$ Department of Community Medicine, Subharti Medical College, Meerut (UP), India \\ ${ }^{3}$ Director Jain Medical Center, Kanpur, Uttar Pradesh, India
}

\begin{abstract}
Background: With modest $1.3 \%$ of GDP spent on health, India is yet to develop robust primary care, quality emergency response infrastructure, and a surveillance system which can manage COVID 2019 infections Community Transmission with Corona +ve load of 8360 by $15^{\text {th }}$ April 2020. Objective: So a Study of analysis of available cases pointing towards Community Transmission is urgently needed in India by new kind of WTSO analysis approach.
\end{abstract}

Material \& methods: As per latest articles available in Websites, search of various studies in any form ;using 3 key search words: ", Community Transmission, COVID 2019 Infection, Indian Cases" was done using websites of Google, PubMed, EMBASE, MEDLINE, Global Health, Psyc-INFO, Biomed-Central, Web of Science, Cochrane Library, world library - World-Cat, from 1 January, 2020 to $15^{\text {th }}$ April 2020 by summarising information of available Indian Cases.

Results: Available 22 Indian cases analysis Including (18) HOT Spots cases in Literature reveals that with no international travel history or history of no contacts, moreover cases hiding and escapes from Isolation wards raises a Point of Possible budding of Community transmission in India, but nothing can be said very conclusively.

Conclusion: Although experts at the ICMR feel that,while, India is at stage 2 now, stage 3 of community transmission have not yet come out. But if strict lockdown related precautions such as social distancing are not taken seriously by general public, stage 3 may come soon in India as evident from our analyses by a WTSO approach applied on available cases.

\section{Introduction}

According to WHO( 2020) Situation Report\& MOHFW data the number of COVID-19 infections have reached 300,000 globally and Global risk level is still very high and India has already crossed 8356 cases by $12^{\text {th }}$ April 2020 (including 71 foreign nationals) have been reported in 31 states/union territories( Including 715 who have been cured/discharged, 1 who has migrated and 273 deaths). For this the Hospital isolation of all confirmed cases, tracing and home quarantine of the contacts is ongoing aggressively. But the real pinjt is that the India is a hugely populous country with high density of 455 people/ km. Moreover India has only 0.7 beds per 1000 polpoulation and an evolving public health system largely occupied by private health services.The real Problematic question is with this health Scenario, how India can prevent COVID 2019 epidemic Community transmission in India.

Many studies across the world including that of John JT (2020) across the globe hint towards budding Community transmission across the globe including India. Community transmission, without contact with persons with COVID-19, is already seen a recognised threat in other countries such as Singapore and US [1].

The number of infections is increasing rapidly in India too; as of March 11, 63 infected people had been detected. As the virus adapts more to humans over time, we expect its virulence declining but infectiousness increasing. It is likely 
that the virus will spread universally, like a pandemic flu, and finally may become endemic. This projection is not comforting as mortality depends on spread, virulence and healthcare standards [1].

Moreover the epidemic of COVID-19, instils fear and anxiety due to its rapid spread, many deaths, lack of specific treatment and gaps in our knowledge about its spread and behaviour. The current epidemic is unlike all previous ones is mighty spreader and moderate killer [1]. India's nodal health research body ICMR says that the country is only facing local transmission of the virus as of now. Sporadic cases with no travel history have been seen in the country. This shows there is community transmission of some degree [2]

Moreover there are many cases which are hinting towards budding Community Transmission in India also as seen in few cases in states of MP $(n=5)$, Karnataka $(n=2)$, Tamilnadu $(n=$ 1), Punjab ( $n=1)$ as per website information. These people do not have any foreign travel history or contacts exposure [3].

No-doudt the effort of Govt of India is marvellous on this front and experts at the ICMR also feel that India is at stage 2 now, but, stage 3 may become Inevitable in India, if strict measures are not followed by general public. Although many articles are emerging on this research area in literature, but the combined effect of isolated cases as evidence for community transmission are yet to be proved. So this research area needs more precise information for taking public health action. A WTSO analysis approaches like we did is therefore urgently needed for saving our human community. That's why this study was done by authors

\section{Material and methods}

As per latest articles available in Websites, search of various studies in any form ;using four key search words: "TOWS Analysis, Community Transmission, COVId 2019 Infection, Indian Cases" was done using websites of Google, PubMed, EMBASE, MEDLINE, Global Health, Psyc-INFO, Biomed-Central, Web of Science, Cochrane Library, world library - World-Cat, from 1 January, 2020 to $15^{\text {th }}$ April 2020 for summarising information of available Indian Cases.

\section{Results}

The 15 days analysis of cases as available from data of MOHFW, GOI is given below in Table 1 reveals a variable scenario testing and rapidly rising COVID 2019 Epidemic in India:

The Results of further Cases analysis derived from 21 Cases as given in Table 2 .

\section{Cases pointing towards start of community transmis- sion in india}

The available 22 Indian cases analysis in Literature (Table 2) reveals that with no international travel history or history of no contacts raises a Point of Possible budding of Community

transmission in India, but nothing can be said very conclusively at this staage.But few important cases issues which needs strict attention are as given below:

\section{Cases of tamil nadu \& pune}

Govt now also feels that India is in start of Phase 3, which appears from Reported cases scenario. If we see few cases such as One case of a 20-year-old male living in Tamil Nadu, which tested positive on March 21 was a 'domestic case with no travel history'.The second case was of a 41-year-old Pune woman, which confirmed positive on March 20.. However, the government feels that these are only isolated community transmission cases, as their contract tracing is still on [4].

\section{Delhi case}

Another case of Nisha in Delhi: She had no recent history of travel to any affected country and has not been in contact with any confirmed Covid-19 case points towards community transmission, It is likely that from this kind of case that the disease is spreading in the community and most of these kind of cases are yet to be found [5]

\section{Neumonia cases}

Just recently 10 pneumonia patients, with no history of foreign travel or contact with a Covid-19 confirmed case, have tested positive( ICMR Report $30^{\text {th }}$ March 2020) [5]. This Points towards possible beginning of Community Transmission in India.

Table 1: Date wise analysis of COVID-19 cases in India( 15 Days)

\begin{tabular}{|c|c|c|}
\hline Date & \multicolumn{2}{|c|}{ No of cases( \% change)[ MOHFW Report] } \\
\hline $2020-03-29$ & $1,024(+106)$ & $(+12 \%)$ \\
\hline $2020-03-30$ & $1,251(+227)$ & $(+22 \%)$ \\
\hline $2020-03-31$ & $1,397(+146)$ & $(+12 \%)$ \\
\hline $2020-04-01$ & $1,834(+437)$ & $(+31 \%)$ \\
\hline $2020-04-02$ & $2,069(+235)$ & $(+13 \%)$ \\
\hline $2020-04-03$ & $2,547(+478)$ & $(+23 \%)$ \\
\hline $2020-04-04$ & $3,072(+525)$ & $(+21 \%)$ \\
\hline $2020-04-05$ & $3,577(+505)$ & $(+16 \%)$ \\
\hline $2020-04-06$ & $4,281(+704)$ & $(+20 \%)$ \\
\hline $2020-04-07$ & $4,789(+508)$ & $(+12 \%)$ \\
\hline $2020-04-08$ & $5,274(+485)$ & $(+10 \%)$ \\
\hline $2020-04-09$ & $5,865(+591)$ & $(+11 \%)$ \\
\hline $2020-04-10$ & $6,761(+896)$ & $(+15 \%)$ \\
\hline $2020-04-11$ & $7,529(+768)$ & $(+11 \%)$ \\
\hline $2020-04-12$ & $8,447(+918)$ & $(+12 \%$ \\
\hline Summary of test results (Till 11 th April 2020) [ICMR REPORT] & \\
\hline Samples tested & & 179,374 \\
\hline & Tested positive & \\
\hline
\end{tabular}

Citation: Davey S, Davey A, Jain R (2020) Possibility of Community Transmission of COVID 2019 Infection In India: A WTSO Analysis Outcomes. Arch Community Med Public Health 6(1): 069-073. DOI: https://dx.doi.org/10.17352/2455-5479.000080 
Table 2: Scenario of Possibly budding Community transmission of COVID 2019 Infection in India.

\begin{tabular}{|c|c|c|c|c|c|c|c|}
\hline Sr No & Case Example & $\begin{array}{l}\text { Evidence of } \\
\text { Information }\end{array}$ & City of Cases & $\begin{array}{l}\text { No of Cases considered } \\
\qquad[\mathrm{N}=40]\end{array}$ & $\begin{array}{c}\text { H/o International } \\
\text { Travel }\end{array}$ & $\begin{array}{l}\text { H/O of Contact } \\
\text { with Corona } \\
\text { Positive case }\end{array}$ & Outcome \\
\hline 1 & $\begin{array}{l}\text { India SIM Model Report } \\
\text { [CDEPP] }\end{array}$ & $\begin{array}{l}\text { Web based } \\
\text { Report }\end{array}$ & All India & $\begin{array}{l}\text { Overall Projection on } \\
\text { Cases }\end{array}$ & Nil & Nil & $\begin{array}{l}\text { Peak of infections may occur } \\
\text { in } 3 \text { months and there may be } \\
\text { a recurrence in November/ } \\
\text { December }\end{array}$ \\
\hline 2 & John JT & $\begin{array}{c}\text { Website } \\
\text { Information }\end{array}$ & All India & $\begin{array}{c}\text { Overall Projection on } \\
\text { Cases }\end{array}$ & Nil & Nil & $\begin{array}{l}\text { Virus may spread universally, like } \\
\text { a pandemic flu, and finally may } \\
\text { become endemic. }\end{array}$ \\
\hline 3 & $\begin{array}{l}\text { Rothe C, Schunk M, Sothmann } \\
\qquad \text { P et al. }\end{array}$ & $\begin{array}{l}\text { N Engl J Med } \\
2020\end{array}$ & Germany. & $\begin{array}{l}\text { Overall Projection on } \\
\text { Cases }\end{array}$ & Nil & Nil & $\begin{array}{l}\text { Transmission of 2019-nCoV } \\
\text { infection from an asymptomatic } \\
\text { contact }\end{array}$ \\
\hline 4 & $\begin{array}{l}\text { CMHO MP Government } \\
\text { Karnatka Government } \\
\text { Tamilnadu Government } \\
\text { Punjab Government }\end{array}$ & $\begin{array}{c}\text { Website } \\
\text { (Grainmart news) }\end{array}$ & India & $\begin{array}{c}\text { Total-9 cases } \\
5 \text { +veCases } \\
\text { (1 Ujjain \& } 4 \text { Indore } \\
\text { 2+ve cases( } 65 \text { yrs \& } \\
10 \text { mth Old)- } \\
65 \text { Year old-died. } \\
1+\text { ve( } 54 y r) \\
1+\text { ve( } 65 \text { yr male) }\end{array}$ & Nil & Nil & $\begin{array}{l}\text { Possible Community } \\
\text { Transmission Evidence }\end{array}$ \\
\hline 5 & $\begin{array}{c}\text { TN government } \\
\text { Maharashtra Government(Pune0 }\end{array}$ & website & India & $\begin{array}{l}1+\mathrm{ve}(41 \mathrm{yr} \text { male }) \\
1+\mathrm{ve}(21 \mathrm{yr} \text { male })\end{array}$ & Nil & Nil & $\begin{array}{l}\text { Possible Community } \\
\text { Transmission Evidence }\end{array}$ \\
\hline 6 & Delhi government & website & India & 1 ( Female-NISHA) & Nil & Nil & $\begin{array}{l}\text { Possible Community } \\
\text { Transmission Evidence }\end{array}$ \\
\hline 7 & ICMR Reports & website & India & 10 Pneumonia Cases & Nil & Nil & $\begin{array}{l}\text { Possible Community } \\
\text { Transmission Evidence }\end{array}$ \\
\hline 8 & $\begin{array}{c}\text { Hot Spots Examples from Delhi, } \\
\text { Maharashrasthra, Tamilnadu, UP, } \\
\text { Tealangana }\end{array}$ & Website & India & $\begin{array}{c}13 \text { people tested positive } \\
\text { in Dharavi(mubai) area in } \\
\text { a week } \\
5 \text { new Covid-19 hotspots } \\
\text { were added to } 25 \text { exisiting } \\
\text { high-risk zones in Delhi }\end{array}$ & yes & yes & $\begin{array}{l}\text { Possible Community } \\
\text { Transmission Evidence }\end{array}$ \\
\hline
\end{tabular}

\section{Discussion}

\section{Weakness, Threats, Stength \& Oppurtunity (Wtso) analy- sis of cases in indian context}

Few Indian cases points towards possibility of start of Community transmission in India as seen in our WTSO analysis as given further in our article.

\section{Weakness: Post 30 days windows period outbreak due to lockdown \& social distancing failure in some areas of india}

Since Honorable Prime Minister of India announced a 21 day lockdown in the country, there was a large movement of people out of large cities like the capital New Delhi ( At ISBT Anand Vihar/ Koshami BusTand) and the financial centre of Mumbai, trying to reach their homes after their work disappeared overnight. This was a clear violation of lockdown measures in these events to maintain social distance, clearly increasing the risk of Community Transmission in Metro Cities of India. Mathemetical Modelling Study of Singh R \& Adhikari(2020) [6], on impact of social distancing measures has also suggested that a three-week lockdown was found insufficient to prevent a resurgence and, instead, protocols of sustained lockdown with periodic relaxation and at least 50 days lockdown are needed.

Current evidence also suggests that transmission of COVID-19 may be possible even from asymptomatic contacts [7], and polymerase chain reaction testing may not return positive initially [8]. The secondary, hospital-based transmission( due to Opening of Medical Universties, where doctors from one district travel to other district) is also fuelling the COVID epidemic silently. An epidemic in medical \& healthcare institutions, both public and private, therefore can amplify transmission and epidemic peaks. Moreover delays in testing in these institutions can seriously reduce the ability of the population to self-protect. This may become the way in which the epidemic can reach upto stage 3 in India.

Community transmission starts when a patient who is not exposed to positive patient and did not travel to countries where the virus is circulating tests [9]. ICMR also feels that Community transmission of Covid-19 is inevitable as only 30-days window period is available to halt community transmission and this 30 days windows period seems to be ignored in all other countries including Italy, the US and Europe, that's why there a surge in cases in deaths from these countries. So we need to tap this 30-days window period opportunity, if we want to prevent the stage 3 of India's Epidemic.

\section{Threats}

India's epidemic situation (till $15^{\text {th }}$ april 2020): In one study [10], of Sahasranaman A \& Kumar N(2020) on Stage 3 community transmission in India, they suggested that significant proportions of the population being infected by COVID-19 before the epidemic recedes - they simulated these 
possibilities for $R 0=1.5$ (lower end of transmission rates) and $R 0=2.5$ (median transmission rate) and found that with community spread, the maximum infection caseloads of $6 \%$ and $23 \%$ of the population respectively can occur. Even if it is assumed that maximum infection load in India peaks at $6 \%$, (about 80 million people) and even if only $5 \%$ of these cases are most severe requiring intensive care, this means that the Indian health system would need to cater for 4 million ICU beds, but it is estimated that there are only around 100,000 ICU beds in India [11].

Despite the fact that COVID-19 infection rate in India remains low relative to population size. But GOI is still preparing best for curtailing broader outbreak and community transmission. It is expected that peak of infections may rise in 3 months and there may be a recurrence in November/ December as per India SIM Model Report. Therefore plans are needed for temporary treatment facilities across India, focused on severe cases [12].

Moreever experts also believe that enough tests have not been carried out , so community transmission may go undetected without adequate testing [13].

\section{Predictability of community transmission of epidemic based on india SIM Model [CDEPPP] [12]}

IndiaSIM is a mathematical model used for Prediction of Covid 2019 epidemic Progress in India. This model has taken available data from China and Italy on variables of force of infection, age- and gender-specific infection rates, severe infection, and case-fatality rates. According to this Model COVID-19's temperature and humidity cannot be predicted, however india may adopt most likely Scenario of High Trajectory with current lockdowns but insufficient physical distancing or compliance as seen from Media Reports and News Papers. Moreover current ICU- and ventilator-equipped bed capacity in India is also highly inadequate to the number of infections at epidemic peak.Current capacity is only $30-50 \mathrm{~K}$ ventilators nationwide and about $70-100 \mathrm{~K}$ ICU beds. We need expansion of this immediately. We will need 700,000 ICU Beds and 1 million ventilators to manage this peak.

\section{Escaping from Isolation wards in India}

Several cases are reported across the country, where people who are suspected to have come in contact with the virus, escaped from the quarantines and hospitals [14-18]. In Chhattisgarh, a 35 yr-old man from Tagapani, Dhamtari, who was put under isolation home by the health dept after his return from Tamil Nadu, committed suicide. In Gujarat, 93 people broken self-isolation rules in 10 days. Two expats in Kasaragod district, Kerala, who violated quarantine measures were subjected to punitive measures. On 20 March, A case of 26-year-old woman suspected of being infected with the corona virus has been reported to have fled the hospital in Punjab. The woman, who hails from Mohali, recently returned from the US and was brought to a government hospital in Chandigarh. On 13 March in Telangana, one woman returned from Singapore has been missing, while a man who came from Doha went somewhere without telling hospital staff.

\section{Possible community transmission threats from medical institutions \& medical universities}

Due to COVID 2019 mortality in healthcare staff can increase deaths in the general population. Without Proper infection control strategy, healthcare workers can get sick, further straining the capacity of the healthcare system. Moreover lack of Social distancing, Gatherings in CME halls even for Covid 2019 Online training in Hospitals Inside Campuses of Medical Institutions/ Medical University can become the real culprits for beginning Community Transmission in India. So the approach of ABOSULTE LOCKDOWN EVEN Medical Institutions/ Medical University needs to be followed urgently. Only COVID 2019 Management Doctors and staff needs to be present in hospitals. Rest of medical Clinical \& Non Clinical faculty needs to kept on STANDBY MODE as B or C team for future rising epidemic, if needed.

\section{Challenges in de-isolation}

Table 2 operational challenges remain in the de-isolation of suspected cases. With substantial numbers of suspected cases admitted for isolation and the need to hold patients for repeated testing, there is an urgenta need to manage isolation room occupancy. However, for patients who needed ongoing inpatient care for other reasons, we also needed to address the risk of inadvertent nosocomial amplification, to reduce the risk of transmission from patients who had tested negative early in their clinical illness. A rigorous framework is urgently required to help clinicians de-isolate COVID-19 patients safely [19].

\section{Opportunities}

Options for curtailing india's epidemic [12]: Given the high risk of infections and low levels of infection control in hospitals including urban areas, it is important to avoid admitting COVID-19 patients in regular health facilities. We need to consider how much care can be delivered at home. There is a need for large, temporary hospitals to handle this patient load over the next three-month period and for this India's Option of ISOLATION WARDS IN STOPPED TRAINS is very applauding action in this regard. Although national lockdown has been done in good favour of Indian Citizens but it may damage our economy, demand of hunger, and can reduce the population resilience for the infection peak. Some states may see transmission increase only after another 2 weeks. State-level lockdowns in the most affected states could change the trajectory of the epidemic, but should continue at least 1-2 months. Lockdowns also needs urgent support of testing and serological survey data on rolling basis.Currently till $15^{\text {th }}$ April 2020 the low levels of testing and an almost complete absence of testing for community spread, there is significant risk that we may be missing out on the actual nature of outbreak. India still has an apparently low current caseload, with possibly a small window of time to act, and should therefore aggressively and systematically expand random testing for community spread, including for asymptomatic cases.

Study [20], of Mandal S et al( 2020) also reveal that symptomatic quarantine would identify and quarantine 50 per cent of symptomatic individuals within three days of developing symptoms. In an optimistic scenario of the basic reproduction number (R00) being 1.5, and asymptomatic infections lacking

Citation: Davey S, Davey A, Jain R (2020) Possibility of Community Transmission of COVID 2019 Infection In India: A WTSO Analysis Outcomes. Arch Community Med 
any infectiousness, such measures would reduce the cumulative incidence by 62 per cent. In the pessimistic scenario of Ro=4, and asymptomatic infections being half as infectious as symptomatic, this projected impact falls to two per cent but once the virus establishes transmission within the community, quarantine of symptomatics may have a meaningful impact on disease burden.

\section{Strengths:- india following china \& singapore efforts}

Many good measures has been taken by Govt of India just similar to the efforts of affected countries such as China, South Korea \& Singapore. In Singapore study [21], of 100 Cases it was revealed that a multipronged surveillance and containment strategy achieved case ascertainment and slowing of the outbreak. From this strategy the mean interval from symptom onset to isolation was reduced from 5.6 days after 1 month [9].

China's strategy for epidemic prevention by use of AI, big data and other scientific measures, effective policy implementation and deep commitment can also help India by adopting this strategy to cope up with the current Epidemic. On the other hand, India can also learn from South Korea's strategy to flatten the curve with a rigorous testing regime and clear public information. The voluntary efforts in National Lockdown \& Social Distancing needs also to be promoted by persuasion, shared understanding and common ownership [9].

India's government is also well managing quarantine migrant workers and preventing the movement of people across borders to contain the spread [21-24]. Moreover these Migrant workers are arranged to be kept in state-run quarantine facilities and are offered given shelter and food to those stranded due to the lockdown. Just recently India in last week of March 2020, has revised its Covid-19 testing strategy [21-24]. As per new guidelines by the Indian Council of Medical Research (ICMR) state all pneumonia patients can be tested and hospitals across the country can do to testing of all patients admitted with severe respiratory illnesses [25]. The new guidelines also indicate that asymptomatic direct and high-risk contacts of a confirmed case should be tested once between Day 5 and Day 14 of coming in to the contact of infected person [5].

\section{Conclusion}

Despite all good efforts by Govt of India such as nation wide lockdown \& social distancing. The weak adoption of such measures by general public is exposing India to stage 3 of Epidemic now. A multipronged surveillance strategy with enhanced case detection is therefore needed to get a real picture of community transmission in India. So further research is also urgently needed in India on Community Transmission COVID-2019 epidemic in India.

\section{References}

1. John JT (2020) Coronavirus: Why India Will Pay a Great Price Without a National Task-Force. Link: https://bit.ly/3fwOLNi
2. Community Transmission of Coronavirus infection yet. Link: https://bit.ly/3dqhiAr

3. Kaur G (2020) Clear Evidence of Community Transmission of COVID-19 in India as Health Ministry Still Adamant on 'No Community Transmission. Link: https://bit.ly/35IAwyH

4. COVID-19: Has community transmission begun in India?. Link: https://bit.ly/3b7YTqE

5. Indian Council Of Medical Research Department Of Health Research Revised Strategy of COVID19 testing in India. Link: https://bit.ly/3cflemq

6. Singh R, Adhikari R (2003) Age-structured impact of social distancing on the COVID-19 epidemic in India. Quantitative biology. Link: https://bit.ly/3frkhut

7. Rothe C, SchunkM, Sothmann P, Bretzel G, Froeschl G, et al. (2020)Transmission of 2019-nCoV infection from an asymptomatic contact in Germany. N Engl J Med. Link: https://bit.ly/2SNVo26

8. Xie X, Zhong Z, Zhao W, Zheng W, Wang F, et al. (2020) Chest CT for typical 2019-nCoV pneumonia: relationship to negative RT-PCR testing. Radiology. Link: https://bit.ly/2YJb2Qf

9. Research matters. Link: https://bit.ly/2WBtAiF

10. Sahasranaman A, Kumar N (2020) Network structure of COVID-19 spread and the lacuna in India's testing strategy. Link: https://bit.ly/2ytEWNR

11. BBC. Interview with Ramanan Laxminarayan. Link: https://bbc.in/2WGBuqW

12. COVID-19 Modeling the Spread and Prevention of COVID-19. Link: https://bit.ly/35I7iA7

13. Staff, Scroll. Is India testing enough for coronavirus cases?. Link: https://bit.ly/3fz6Sk6

14. 11 coronavirus suspects in Navi Mumbai traced, readmitted. ANI News. Link: https://bit.ly/2WdBAY7

15. 5 coronavirus suspects escape from isolation ward of Nagpur hospital, all traced. Hindustan Times. Link: https://bit.ly/3bgqUwd

16. Chhattisgarh: Covid-19 suspect under home quarantine commits suicide in Dhamtari. Times of india. Link: https://bit.ly/2WduWRP

17. Ghosh, Sohini; Jha, Vaibhav (23 March 2020). In Gujarat, 93 flouted selfisolation rules in 10 days, FIRs against 10. Link: https://bit.ly/3ftd10x

18. Passports ofx two NRIs to be cancelled for violating quarantine orders in Kasaragod. Link: https://bit.ly/2zgNVC2

19. Tay JY, Lim PL, Marimuthu K, Sadarangani PS, Ling LM, et al. (2020) De-isolating Coronavirus Disease 2019 Suspected Cases: A Continuing Challenge. Clin Infect Dis ciaa179. Link: https://bit.ly/3bdmJ4q

20. Mandal S, Bhatnagar T, Arinaminpathy N, Agarwal A, Chowdhury A, et al (2020) Prudent public health intervention strategies to control the coronavirus disease 2019 transmission in India: A mathematical model-based approach. 151. Link: https://bit.ly/3dxAiNH

21. Community transmission of Covid-19 is inevitable: ICMR Link: https://bit.ly/3ca386l

22. Coronavirus: India orders states to quarantine labourers as infections rise Link: https://bit.ly/3fukhJT

23. COVID-19: Has community transmission begun in India? Link https://bit.ly/3dl4aMW

24. Tiwari S (2020) As Government Denies Coronavirus Community Transmission, Experts Say Too Few Tested To Know. Link: https://bit.ly/3cgLIKC

Copyright: (C) 2020 Davey S, et al. This is an open-access article distributed under the terms of the Creative Commons Attribution License, which permits unrestricted use, distribution, and reproduction in any medium, provided the original author and source are credited.

Citation: Davey S, Davey A, Jain R (2020) Possibility of Community Transmission of COVID 2019 Infection In India: A WTSO Analysis Outcomes. Arch Community Med Public Health 6(1): 069-073. DOI: https://dx.doi.org/10.17352/2455-5479.000080 